Canadian University Music Review

Canadian University Music Review

Revue de musique des universités canadiennes

\title{
Karol Szymanowski and Richard Strauss: Of Diverging Epiphanies
}

\section{Paul Cadrin}

Volume 24, numéro 2, 2004

URI : https://id.erudit.org/iderudit/1014581ar

DOI : https://doi.org/10.7202/1014581ar

Aller au sommaire du numéro

\section{Éditeur(s)}

Canadian University Music Society / Société de musique des universités canadiennes

ISSN

0710-0353 (imprimé)

2291-2436 (numérique)

Découvrir la revue

Citer cet article

Cadrin, P. (2004). Karol Szymanowski and Richard Strauss: Of Diverging Epiphanies. Canadian University Music Review / Revue de musique des universités canadiennes, 24(2), 29-43. https://doi.org/10.7202/1014581ar
Résumé de l'article

D’après le philosophe Charles Taylor, depuis l'avènement du Romantisme, au début du dix-neuvième siècle, l'œuvre d'art se définit par son caractère épiphanique. Elle est le lieu de la manifestation d'une réalité de la plus haute importance morale et spirituelle; cette manifestation n'est pas purement subjective, ce qui la rendrait imperméable à l'examen scientifique, mais elle a un caractère objectif. La Troisième symphonie, op. 27, par Karol Szymanowski est analysée à la lumière de la théorie de Taylor. La Deutsche Mofette, op. 62, de Richard Strauss, basée sur un texte similaire à celui utilisé par Szymanowski, sert de repoussoir pour confirmer les conclusions.
All Rights Reserved (C Canadian University Music Society / Société de musique des universités canadiennes, 2005
Ce document est protégé par la loi sur le droit d'auteur. L’utilisation des services d'Érudit (y compris la reproduction) est assujettie à sa politique d'utilisation que vous pouvez consulter en ligne.

https://apropos.erudit.org/fr/usagers/politique-dutilisation/ 


\title{
KAROL SZYMANOWSKI AND RICHARD STRAUSS: OF DIVERGING EPIPHANIES
}

\section{Paul Cadrin}

To describe the role played by the work of art since the Romantics, the philosopher Charles Taylor, in his remarkable book, Sources of the Self: the Making of the Modern Identity, has coined the term "epiphany"; while he borrows this term from Joyce, Taylor uses it in a broader sense. Although his initial definition of what constitutes an epiphany is not the most illuminating-one has to read through the relevant chapter to get a better grasp of what he means-this definition has to be our starting point.

\begin{abstract}
What I want to capture with this term is this notion of a work of art as the locus of a manifestation which brings us into the presence of something which is otherwise inaccessible, and which is of the highest moral or spiritual significance; a manifestation, moreover, which also defines or completes something, even as it reveals. (Taylor 1989, 419)
\end{abstract}

Since this characteristic of the work of art lies at the core of this paper, a deeper understanding is needed before we can use it as an analytical tool.

The revelation brought about by the work of art should not be equated with a reading of the intentions of the author or of the composer. "The work must be understood independently of whatever intentions the author has formulated in relation to it...." (Taylor 1989, 420). Certainly, before the nineteenth century, there have been works of art which were intended to convey a "greater spiritual reality." But this was achieved through the mediation of allegories, therefore by referring to realities outside the work of art itself. There lies the basic difference between these works and those of the Romantics: "The work remains the locus of revelation, and of something of ultimate significance, but it is also utterly self-contained and self-sufficient" (Taylor 1989, 420).

Allegories are replaced with symbols and images, and these, in turn, are totally fused within the work of art. This is clearly expressed by the Irish poet William Butler Yeats, quoted by Taylor: "A symbol is indeed the only possible expression of some invisible essence, a transparent lamp about a spiritual flame; while allegory is one of many possible representations of an embodied thing or a familiar principle" (Yeats, quoted by Taylor 1989, 421).

With the advent of Romanticism, not only are allegories shunned in favour of symbols, but the relationships between the work of art and the morally good undergo a deep transformation. The work of art belongs to the universe of the aesthetic, which is deemed by nineteenth-century authors to be of a higher 
order than that of morality. [For Schiller] “... the aesthetic offer[s] a higher fulfilment than the merely moral, because the moral only realizes one side of us, form and not matter, while beauty can make us whole, give us harmony and freedom" (Taylor 1989, 422).

The creative imagination, which is the source of the work of art, becomes "the locus of moral sources" (Taylor 1989, 426). This reliance on the creative imagination not only for the production of the work of art but even for its spiritual and moral valuation induces "a subject-centredness which is much more insidious than the thematic penchant for self-expression" (Taylor 1989, 429) usually ascribed to the Romantics. Thus "a certain subjectivism is inseparable from modern epiphanies... we can't escape the mediation through the imagination" (Taylor 1989, 428).

The emergence of the epiphanic character of the work of art in the Romantic era has achieved an irreversible change of paradigms: "There are strong continuities from the Romantic period...right up to the present day. What remains central is the notion of the work of art as issuing from or realizing an 'epiphany'..." (Taylor 1989, 419).

With these points in mind, we are ready to flesh out Taylor's initial definition. Epiphany is that aspect of a work of art through which it becomes the locus of a manifestation which, via the mediation of symbols, makes present, in its own unique way, a transcendent reality - a reality which would otherwise remain inaccessible - and which, since it is a product of the creative imagination, defines-as it reveals-its own moral universe. This epiphanic function is found not only in works belonging to the Romantic era, but is a significant characteristic of the work of art to this day.

\section{ANALYZING MUSIC IN THE LIGHT OF TAYLOR'S EPIPHANY}

In the last quarter of the twentieth century, music analysis has distanced itself from compositional theory and from aesthetics in order to focus on the structures and operations inherent to the work, without any interference from or inferences to considerations outside the composition itself. This lofty stand-point could barely disguise the almost aggressive stance taken by analysts towards compositional theory, music criticism, aesthetics, including any kind of philosophical inquiry. In those analysts' view, the application of these disciplines to the understanding of music was dependent on subjective evaluations, and therefore was lacking in the objectivity required for a scientific enterprise. Recent researches in musical scholarship have adopted a more inclusive standpoint and fresh openings are being made to the influence of philosophy and psychology. The concept of epiphany, as it was brought to light by Charles Taylor, however, has yet to yield its fruits in the field of music analysis.

On the one hand, Taylor sides with those analysts in emphasizing the immanent character of the epiphany: "the locus of epiphany has shifted to within the work itself'(Taylor 1989, 419). But, on the other hand, because it is epiphanic, the artwork "remains the locus of revelation, of something of ultimate significance" (Taylor 1989, 420). A material scrutiny of the parts of a composition and of their inter-relationships, however meticulous, cannot do 
justice to its revelatory character. This revelation is not purely subjective. In fact, it is not subjective at all, because: "in the work of art, the universal term is inseparable from, is identified with, its instantiation. A beautiful object is a particular which carries universal import" (Taylor 1989, 421). Therefore, from this perspective, the kind of objective, detailed scrutiny which the analyst prefers should logically lead to a clarification of those epiphanies "where something of great moral or spiritual significance becomes manifest" (Taylor 1989, 423). This is certainly a challenge that most analysts have been wary of facing in the last 30 years. Of their approach, Taylor says that it "is gravely defective. It leaves out entirely the epiphanic dimension" (Taylor 1989, 487).

I dare take up this challenge, and try to elucidate some of the epiphanic dimensions of a major composition by Karol Szymanowski (1882-1937), his Third Symphony, op. 27, for tenor solo, choir and orchestra, subtitled "The Song of the Night." It is based on a poem by the thirteenth-century Persian poet and mystic Jalâl al-Din Rumi. In order to buttress my conclusions, I will use as a foil a work by Richard Strauss (1864-1949), his Deutsche Motette, op. 62, for a cappella chorus, based on a poem by Friedrich Rückert. As I hope to demonstrate, these two works, which were composed within three years of each another, were born out of very similar intentions, but their profound differences beget highly diverging epiphanies. ${ }^{1}$

In trying to elucidate the epiphanic character of these two works, one should not be deceived by the presence of a text into thinking that this will make the task any easier. The text certainly carries revelatory elements of its own. But in setting it to music, the composer may or may not have emphasized these ingredients; he may even have introduced altogether new and foreign elements. Therefore a careful examination of both the text and the music, as well as the relationship between them, is of critical importance.

\section{THE TEXT AS EPIPHANY}

\section{Jalâl al-Din Rumi : Poem from the Divân-e Shams}

The poem used by Szymanowski was originally written by Jalâl al-Din Rumi (1207-1273), founder of the Mevlevi, the spiritual order famous for its ritual turning dances. ${ }^{2}$ The current wave of interest in Rumi is not the first to hit the Western hemisphere. A similar, albeit much more modest vogue occurred at the end of the nineteenth century. At the time, it was sparked by the publication of Rumi's poems for the first time in European languages. This started in the German-speaking world thanks to Joseph von Hammer (1774-1856), ${ }^{3}$ an

1 For a full understanding of the present discussion, it is hoped that the reader has access at least to the lyrics of both works, which are usually included with good recordings.

2 All information about Rumi are taken from Franklin D. Lewis' recent and most thorough book (Lewis 2000).

3 Also known as Joseph, Baron von Hammer-Purgstall. When the death of her only son left her heirless, in 1817, the Countess of Purgstall (born Cranstoun, a native of Scotland) donated her estate to von Hammer, on condition that he add "Purgstall" to his name after her death, which occurred in 1835. 
Austrian linguist of immense erudition. In writing his symphony, Szymanowski used a translation into Polish, by the poet Tadeusz Miciński (18731918), of von Hammer's German version.

Rumi is contemplating the Oriental sky at night, and is urging his unnamed companion to share in the mystical elation that this vision triggers in him. Many dimensions of this text appear to be of epiphanic import. The poem conveys an intense experience of the presence of God, but of God as he manifests himself in nature. Far from closing off his senses in order to find God within himself, the poet wants to be fully atuned to the world surrounding him and to its broadest manifestations. His experience of God is mediated through nature. In the words of Jim Samson: "The expression of man's relationship to God is direct and often sensuous, using erotic imagery and images of intoxication to convey spiritual love" (Samson 1980, 121). This should not be interpreted as a form of pantheism, however-and here I take exception with Samson. God is not experienced as a kind of energy scattered throughout nature, but as a person whose presence is felt in nature. This experience of God's presence is only possible through the intoxicating effects night has on the senses. There is no doubt that this uncanny state is pleasant, even highly desirable, if we are to believe the poet's repeated invitations to follow him on that route.

A detailed analysis of the poetic structure of Rumi's text is not in order here, but I would like to draw attention to four aspects whose importance will become manifest when we examine its musical setting, as well as when we compare it with the text used by Richard Strauss.

1. This divine experience is not an outcome of the moral integrity of the poet, and it doesn't come as a reward for having fulfilled some sort of mission. The only condition for it to happen is to develop a heightened awareness to beauty and to love. "Certainly Szymanowski's preoccupation with a Dionysian cult of beauty and love was given added stimulus by Persian mystical poetry" (Samson 1980, 121).

2. At the beginning and end of the text, the poet is speaking to a companion, urging him (her?) to stay awake; transfigured by love, this companion becomes himself a divine manifestation ("You are Spirit"). Later on, the poet says "God and I are alone tonight." What happened to the companion, one may ask? My understanding of this disappearance is that the experience of the presence of God is one that is so deeply personal that it induces a feeling of separation from the rest of humankind - not to be equated with a separation from Nature, as is obvious from the rest of the poem.

3. In the same way that the poet wants to be fully attuned to his surroundings, he is vigorously focused on the present moment: no reference is made to any past or future event. The intensity of the immediate experience is such as to obliterate any memory as well as any anticipation, and, certainly, any allusion to future retribution or bliss.

4. The main poetic element of the original Persian text retained in the translation is the refrain (or radif) (Lewis 2000, 617), which becomes, in Polish, "Nocy tej" [This night]. This refrain occurs at the end of 15 of the 24 
verses, but its distribution doesn't follow any observable pattern. ${ }^{4}$ Apart from this recurring element, the Polish translation is not structured along a regular versification scheme. This irregular rhythmic structure and the uneven distribution of refrains are epiphanic of a universe in which the human mind doesn't succeed in imposing its need for bi-lateral symmetry and rhythmic regularity. In fact, it doesn't even try to impose such regularities and prefers the exuberant eccentricities of Nature left to its own devices to the stifling rational order which the human mind would be inclined to prefer.

\section{FRIEDRICH RÜCKERT: DIE SCHÖPFUNG IST ZU RUH GEGANGEN}

The poem chosen by Richard Strauss for his German Motet was written by Friedrich Rückert, obviously under the influence of Rumi, as Lewis testifies (Lewis 2000, 617). Rückert, who had been a student of von Hammer, had made a fresh translation of Rumi into German.

Contrasts between Rückert's and Rumi's poems run deep, however. Rückert's unnamed Supreme Being ("God"?) is not found in Nature, but outside and above it. This "God" can only be met by turning inwards and putting one's senses to sleep, notably through the ultimate sleep of death. Nature itself is felt as a hostile environment. Night doesn't convey a pleasant experience. It is the realm of evil, a prison where the forces of darkness loom. ${ }^{5}$ Much as Rumi is elated by his immediate experience of the presence of God in nature, Rückert is moved to fear both by his present condition and by his anticipation of Doomsday. This fear is tempered, however, by his hope in "God's" kindness. But to benefit from this kindness, the poet feels he must first fulfill the task he has been assigned by this anonymous Spirit. His hope is one of reward in the after-life. Thus Rückert's text carries strong moral overtones that are entirely foreign to Rumi's poem. This is a plea laid directly before "God." No companion or witness is present. The difference of attitude between Rumi and Rückert with respect to time is telling. While Rumi's poem is an invitation to be fully attuned to the uniqueness of the present moment, Rückert's is entirely turned to the future, prominently to that ultimate future, the Last Judgment.

When one looks at the verse structure of Rückert's text, one is immediately struck by its perfect regularity. It uses the hexameter, the venerable verse form of the Epic, including its typical subdivision into a tetrameter and a distich for the refrain. The return of the refrain, every second verse, is perfectly regular: "In slumber all the world reposeth, o wake in me!"6 The very structure of this

4This must not be understood as referring to the original Persian text, but, since Szymanowski only had access to the Polish translation, reference to the original is irrelevant for our purposes.

5In her article on "Richard Strauss A Cappella" [Tempo no. 176 (1991) 21-28], Judith Blezzard writes that Ruckert's text uses "the picture of daybreak as a simile for the emergence of the human spirit from the powers of darkness, aided by some unseen force that is never named" (Blezzard 1991, 24). While I am in agreement with the gist of this statement, I have to disagree with its first part ("the picture of daybreak"). I read nothing in the poem suggesting that daybreak is imminent, would it be in a symbolic fashion. On the contrary, everything points to the fact that the poet is plunged in the deepest of nights. 
poem, therefore, is epiphanic of a highly rational world, where regularity and symmetry are basic conditions of beauty, certainly a striking contrast with Rumi's versification.

Therefore, although they deal with a similar topic-a spiritual experience triggered by the contemplation of the sky at night-these are two very different poems. In my view, Rückert's text is an epiphany of nineteenth century, Judeo-Christian values, cast in a moralistic mould, where the world is a sinister, hostile place from which one hopes to escape to rest in "God," a rest which one must become worthy of by fulfilling a mission on earth. Rumi's poem is an epiphany of the presence of God in a lustrous and hospitable nature, a spiritual experience located in the present, intense to the point of bordering on the erotic, and for which one doesn't need to become worthy.

\section{THE MUSIC AS EPIPHANY}

In studying the epiphanic values inherent in the music of Szymanowski's "Song of the Night," my observations will be classified under three headings: texture; melody and tonality/harmony; and form. It may not be very conventional to begin with an analysis of the texture. This parameter is usually dealt with last, if at all. I hope to show that this order is relevant to our purposes.

\section{Texture}

The symphony is scored for a tenor solo, a large choir, and a very large orchestra. A broad array of textures is cut within this impressive fabric, ranging from delicate solos (including solo violin and solo cello parts) to overpowering climaxes. In Samson's words: “... the orchestra is conceived as a reservoir from which may be drawn an infinite variety of timbral combinations. Every performer is called upon to contribute directly and uniquely to this new soundscape, often in an unaccustomed role..."(Samson 1980 113).

By displaying such a rich palette of timbres, Szymanowski depicts a lavish universe bristling with sounds and colours. The importance given to timbre in Western Art music, beginning in the second half of the nineteenth century, is concurrent with an opening to the music and art of non-Western cultures. This trend, sometimes called "exoticism," took on a broad variety of hues, depending on which culture was making its influence felt. Between 1911 and 1914, Szymanowski made a number of trips to Sicily and to North Africa, and his discovery of Arab culture and music was to have a significant impact on his music, notably on the Third Symphony. Whether this symphony is a valid representation of Eastern Mediterranean musical cultures is a moot point. It is certainly heard as such by many listeners, as it was meant to be.

Parallel to this opening to the sounds of musical cultures outside the pale of Western art music, the importance granted to the percussion section, particularly to non-pitched or vaguely pitched instruments, is certainly a by-product

6"Die Schöpfung ist zur Ruh' gegangen, o wach in mir!" (English words by Alfred Kalisch, in the score; Strauss 1943). 
of the democratization of the composer's palette at the turn of the twentieth century. The barriers erected between sounds which were deemed noble enough for making music-produced by pitched instruments-and the commonplace sounds of everyday life, normally classified as noise, are falling. This trend will reach its apex after 1948 with the advent of musique concrète, but it is already well under way at the time of Szymanowski, as this symphony testifies.

In addition to the considerable instrumental forces required for its performance, this symphony calls for the participation of a tenor solo and a choir. While it plays a significant role in defining the sense of the work, the human element, the voice, is bathed in the sounds of Nature, represented by the instruments of the orchestra. It thus appears as an epiphany of humankind which, by the use of language, lends meaning to Nature in which it is immersed. In Rumi and Szymanowski's perspective, to witness this verity is to experience a spiritual illumination of a quasi-erotic intensity.

Again, the texture chosen by Richard Strauss for his German Motet can be used as a foil for our examination of Szymanowski's symphony. The Motet is scored for a 16-part a cappella chorus of uncommon competence, to which are added four soloists (one per part), plus a brief trio of sopranos borrowed from the full choir-a total of 23 distinct parts. In our culture, the a cappella chorus is associated, first and foremost, with Church music of the Renaissance-notably the music of Palestrina, hailed as the paragon of polyphonic writing for the liturgy in Christian churches. The word "motet" in the title ascribed by Strauss-not by Rückert!-emphasizes this connection with Renaissance Church music.

By his own avowal, Strauss was a contented agnostic as well as a committted follower of Nietzsche. This Motet is as close as he will ever get to writing music with religious overtones. Thus, he confers to his work a highly enigmatic epiphanic character: it is a prayer for the modern-day freethinker. In addressing a plea to a "God" presumed to be dead, Strauss calls upon the most explicitly Christian of all sonorities, a cappella polyphony, inflated to unprecedented proportions.

Further epiphanies may be read in this choice. The a cappella mixed chorus is a metaphor for society, a society where men and women are represented on an equal footing, albeit each in their own appropriate range and functions, including a significant overlapping in the middle range. To communicate, these men and women don't need to hide themselves behind instrumental devices, they use the instrument that lies closest to their hearts, their voices. Musically speaking, these people are bare.

Strauss implicitly removes the human race from its natural environment, represented, in Szymanowski's setting, by the wordless sound of instruments. This certainly fits well with what we have already observed in Rückert's poem, in which Nature is perceived as hostile and the poet wishes to close his senses to outside noises in order to move inwards. The single instrument used by Strauss, the voice, is endowed with a skill which differentiates it from every other source of musical sounds: it is capable of language, an attribute unique to the human mind. Thus Richard Strauss's choice of the a cappella chorus is an epiphany of humankind 
both as a society and as isolated from the environment of Nature by its use of language and by its aptitude for introspection and anticipation.

\section{Melody}

I have already mentioned the influence of Arabic music on the textures heard in Szymanowski's symphony. Its influence on the melodic lines is probably even more palpable. The connection between Szymanowski's melodic style and Arabic music is most explicit in the Songs of an Infatuated Muezzin, op. 42, but it is also strongly felt in all the works he wrote between 1912 and $1918 .{ }^{7}$ Szymanowski's approach to folk and ethnic music, however, owes nothing to ethnomusicology and cannot be equated with, for example, Bartók's approach. What we hear in the works of that period is a stylized version of memories he brought back from his travels in North Africa. There is no point in searching for potential sources. It suffices to know that the music is heard as such by a Western listener, in the same way that this listener will hear "Laideronnette, impératrice des pagodes" from Ravel's Ma mère l'Oye Suite as sounding "Chinese", although it is most unlikely that the composer used "authentic" sources for his musical portrayal.

In the symphony, this influence comes across very clearly in the initial melody presented by the violins. It is first heard alone ( $\mathrm{mm} .3-13$, example 1) and later as a counterpoint to the initial phrase of the tenor solo. The entire melody hovers in the high range of the instrument, reaching $a b^{6}$ at its climax (m. 12). The pitches of the whole-tone scale on $C$ are emphasized, with a few exceptions ( $A$ h, $D \sharp, G$ h, $\mathrm{B}$ ң) which, until m. 11 at least, may be understood as passing or embellishing tones, the harmonic support for this phrase being entirely based on that whole-tone scale. Everything concurs in obliterating the specified meter. The third beat is more often chosen as a point of arrival than the first and unstressed syncopations are frequent. Together with the overall profile of the line, these factors suggest an analogy with the kind of voice production that we associate with the cantilena of the muezzin in Eastern Mediterranean culture.

In his landmark study on Folk Song Style and Culture, Alan Lomax has established a strong correlation between the type of voice production preferred in Eastern Mediterranean cultures and the high level of restriction imposed on women's sexual activity (as opposed to the sexual activity of men) in these societies: "Thus we hear, in the high wail of the muezzin, appealing for mercy from Allah, and in the piercing silver tones of the cafe singers, a restatement of the pain, fear, and erotic hysteria of women" (Lomax 1968, 197). As surprising as this may seem, while he intends to depict a colourful, exhuberant and hospitable world where life affirming energies are free to express themselves, Szymanowski uses a type of vocal utterance that speaks of extreme male domination and feminine submissiveness. To do justice to this observation would call for another paper. I will limit myself to two brief remarks.

7Notably the Love Songs of Hafiz, op. 26, the Myths, op. 30, for violin and piano, the Song of a Fairy Princess, op. 31, and the First Violin Concerto, op. 35. 

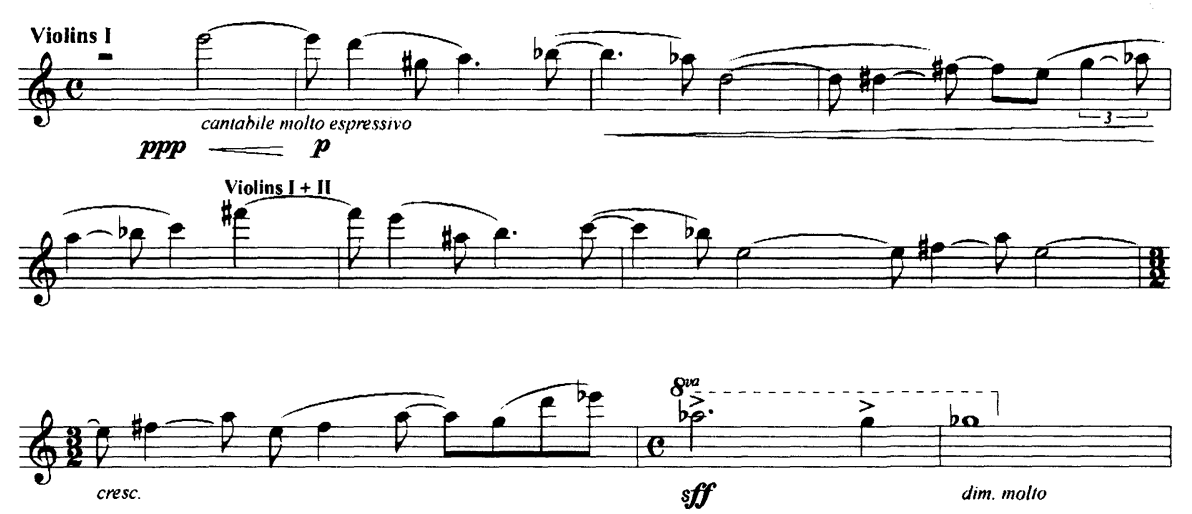

Example 1. Karol Szymanowski, Symphony no. 3, op. 27, Violins I and II, mm. 3-13. (C) 1925, 1953 by Universal Edition A.G., Wien, revised version (C) 1973 by Universal Edition A.G., Wien (C) renewed All Rights Reserved Used by permission of European American Music Distributors LLC, U.S. and Canadian agent for Universal Edition A.G., Wien

First, let us not forget that, as an epiphany, "the work must be understood independently of whatever intentions the author has formulated in relation to it...it is utterly self-contained and self-sufficient" (Taylor 1989, 420). Here would certainly not be the only case where a work of art carries a message unbeknownst to its creator, and even at odds with his most sincerely felt intentions.

Second, while the type of melodic line in question is striking, it is not the only type used by Szymanowski in the symphony. To say that the symphony would be, again unbeknownst to the composer, an epiphany of the kind of male-female relationships that prevail in the Eastern Mediterranean would be an unwarranted generalization.

Here again, the contrast between the style of the symphony and that of the motet is most telling. The fugue subject ( $\mathrm{mm}$. 142-146, example 2) is an excellent point of comparison. Both the key of $\mathrm{D} b$ and common time are clearly established. The prevalent mode is major, and the short-lived inflexion to the minor mode by way of its VI (m. 145) certainly causes no threat to the tonal logic of the phrase.

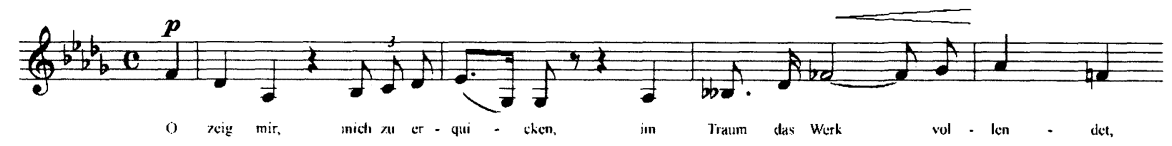

Example 2. Richard Strauss, Deutsche Motette, op. 62, Altos II and Tenors I, mm. 142-146. (C) Copyright 1913 by Adolph Furstner. Copyright Renewed. Copyright Assignment 1943 by Hawkes \& Son (London) Ltd. (a Boosey \& Hawkes company) for the world excluding Germany, Italy, Portugal and the Former Territories of the U.S.S.R. (excluding Estonia, Latvia and Lithuania). Reprinted by permission of Boosey \& Hawkes, Inc 


\section{Tonality and harmony}

As is the case with every work written by Szymanowski after 1914, the tonal-harmonic language of the symphony is a highly personal conflation of sonorities akin to those of the Impressionists, notably of Ravel, with those he had inherited from Skriabin. The composer's upbringing in German neo-romantic music has definitely receded to the background. A short excerpt from the First movement (example 3), shown in harmonic reduction, illustrates this statement.

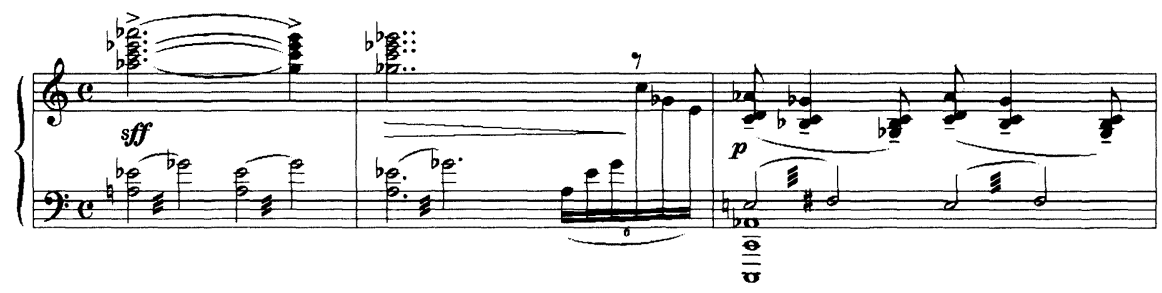

Example 3. Karol Szymanowski, Third Symphony, op. 27, mm. 12-14, harmonic reduction. (C) 1925, 1953 by Universal Edition A.G., Wien, revised version (C) 1973 by Universal Edition A.G., Wien (C) renewed All Rights Reserved Used by permission of European American Music Distributors LLC, U.S. and Canadian agent for Universal Edition A.G., Wien

At mm. 12-13, a diminished seventh sonority ( $\mathrm{A} q-\mathrm{C} q-\mathrm{E} b-\mathrm{G} b)$ is approached by way of an accented major seventh $(\mathrm{B}$ b ) descending chromatically to $\mathrm{A}$. . This diminished seventh chord is followed, at m. 14, with a whole-tone sonority-in fact, the entire whole-tone scale on $\mathrm{C}$ h is heard in that measure. This whole-tone sonority, erected over a pedal of $\mathrm{C} \downarrow$, remains in function for the following seven measures. The step-wise resolution of the major seventh into a diminished seventh chord could be understood as tonally functional at the local level. However, the connection with the following whole-tone sonority is at best tenuous in terms of tonal logic. If any tonal orientation is to be felt in that ambiguous harmonic motion, it is ultimately defined only by the strength of the pedal $\mathrm{C}$ h over which the phrase is erected.

The end of that phrase departs even further from tonal-harmonic conventions (example 4). In m. 21, three pitches foreign to the prevailing whole-tone scale $(F h-G$ $-C \#)$ appear in the two melodic strands active at that point (tenor solo and violins unisono), superimposed over the sustained whole-tone harmony. Dynamics and melodic activity concur in building up to a climax reached on the first beat of $\mathrm{m}$. 22. As may be seen by comparing this example with example 3 , this climax is an exact transposition of $\mathrm{mm}$. 12-13, up by one whole step.

Again, there is no tonal-harmonic logic in the connection between $\mathrm{m} .21$ and $\mathrm{m}$. 22. Apart from the $\mathrm{F}$, the new pitches heard in $\mathrm{m}$. 21 do not anticipate the harmony of $\mathrm{m}$. 22. If they contribute in any way to preparing the motion, it is only by intensifying the harmonic density, therefore generating a tension calling for some kind of release. This release is finally reached in m. 23 on a 


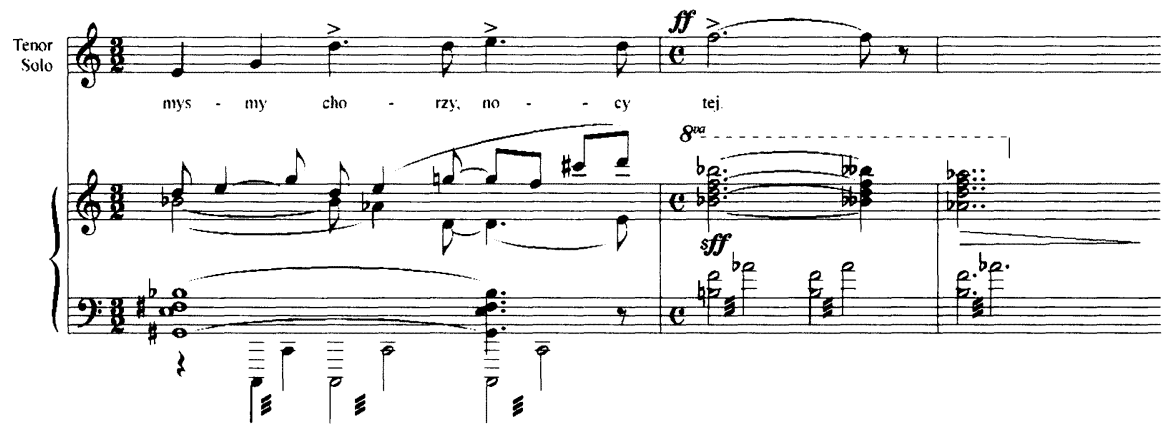

Example 4. Karol Szymanowski, Third Symphony, op. 27, mm. 21-23, harmonic reduction. (C) 1925,1953 by Universal Edition A.G., Wien, revised version (C) 1973 by Universal Edition A.G., Wien (C) renewed All Rights Reserved Used by permission of European American Music Distributors LLC, U.S. and Canadian agent for Universal Edition A.G., Wien

diminished seventh chord ( $\mathrm{B} \nvdash-\mathrm{D} \nvdash-\mathrm{F} \nvdash-\mathrm{A} \#)$ which does nothing to clarify the tonal-harmonic orientation of the phrase, as one would conventionally expect at a point of cadential repose.

The harmonic language of Richard Strauss's motet is unmistakably postWagnerian. An examination of the beginning of the motet illustrates this point (example 5).
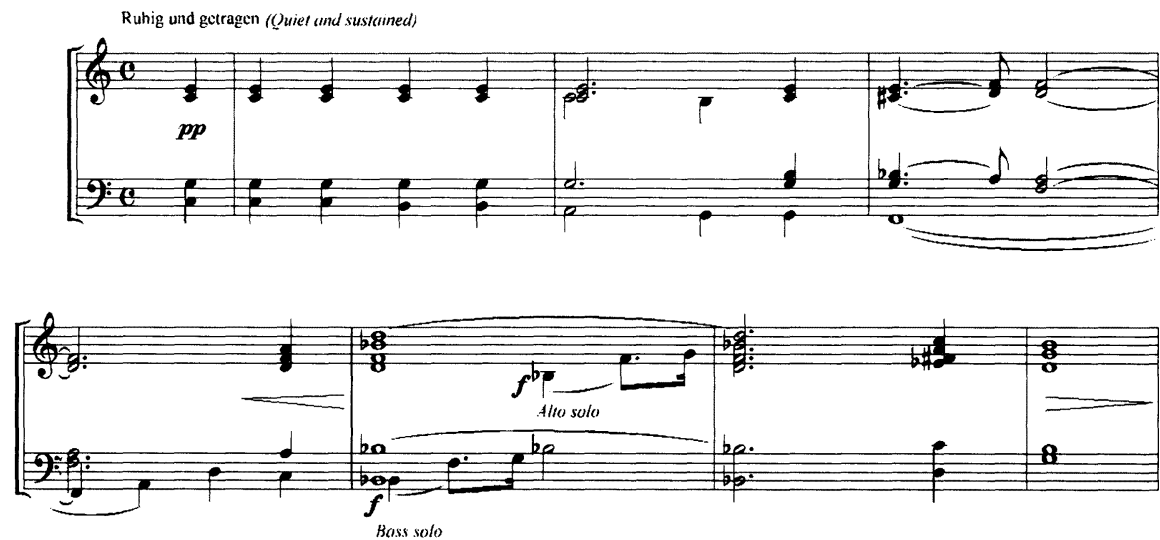

Example 5. Richard Strauss, Deutsche Motette, op. 62, mm. 1-7, harmonic reduction.

(C) Copyright 1913 by Adolph Furstner. Copyright Renewed. Copyright Assignment 1943 by Hawkes \& Son (London) Ltd. (a Boosey \& Hawkes company) for the world excluding Germany, Italy, Portugal and the Former Territories of the U.S.S.R. (excluding Estonia, Latvia and Lithuania). Reprinted by permission of Boosey \& Hawkes, Inc

The first five measures are built over a descending scale in the bass spanning a "major ninth," from $\mathrm{C}$ down to $\mathrm{B} b$ (including an arpeggiated octave transfer, $\mathrm{A} \emptyset$ substituting for $\mathrm{E} \nvdash$ at $\mathrm{m}$. 4), over which similar step-wise descending motions are heard in the inner voices. This combination of motions generates 
all the harmonic activity, including the appoggiatura diminished seventh sonority (over $\mathrm{F}$ h) on the first beat of m. 3, such that non-harmonic tones are all of the passing variety. The lowered VII chord of $\mathrm{m} .5$ is locally re-interpreted as a III in G minor, followed by an imperfect cadence in that key with a tierce de Picardie, reinstating its function as a dominant in $\mathrm{C}$. The listener is gratified with a fine specimen of the skipped passing tone, a significant motive in this work, by the bass and alto solos of $\mathrm{m}$. 5. This short example should be sufficient to illustrate the tonal-harmonic language at work in the motet, and to emphasize the contrast with that of Szymanowski's symphony. There is no lack of chromatic modulation in the Strauss - as we have already seen, the exposition of the fugue is in $\mathrm{D} b$ major-but the motet is unequivocally in $\mathrm{C}$ major.

Given the symbolic significance of the chord of $\mathrm{C}$ major in the works of Richard Strauss-it is the $U r$ chord, the chord of Nature-the importance granted to the tonic chord at the outset of the motet and in the protracted coda does not come as a surprise. Interestingly, this is a feature that it shares with the Szymanowski symphony. In every other aspect, however, their tonal-harmonic languages tread two different paths.

\section{Form}

The formal organization of the symphony is all but simple. In fact, most authors have given up trying to find any kind of formal regularity in this work, to the point of stating that it "bears little relation to the traditional symphonic archetype" (Jeremy Dibble 2001). I have shown elsewhere (Cadrin 2002) that, although the archetypes of the symphony are certainly well disguised, enough of its essential structural elements are present to warrant the use of the label "symphony." In disguising them, Szymanowski was following in the footsteps of Skriabin.

What is true of the general structure of the work is also observed in some details of its phrase structure. In the same way that Rumi's text is not structured along a regular versification pattern, the musical phrases don't follow the kind of regular metrical designs that are the hallmark of the classical symphony. At a deeper level, the symphony diverges from its prototypes in leaving little room for real development in the strict sense of the word. This comment applies to motivic elements as well as to the tonal-harmonic structure. The piece moves forward through the juxtaposition of relatively short segments, rather than by the systematic development of motivic units-examples from Debussy come to mind. On the tonal-harmonic plane, departures from classical norms are substantial. I shall only point to the fact that the climax of what stands for the "development" section (mm. 96-107) is erected on a tonic pedal, a degree that would certainly be avoided in a conventional symphonic structure.

The overall formal structure of the Strauss motet is obviously inspired by the ancient Baroque archetype of the prelude and fugue, here followed by an extended coda, turning what is basically a bi-partite form into a balanced ternary structure. In contrast with the direction chosen by Szymanowski, Strauss does write regular, periodic phrases, and systematically develops his 
motives, using every device in the book. As much as Szymanowski tries to conceal his reliance on the historically dated symphonic archetypes, Strauss enjoys showing his ability to rejuvenate the ancient structures and techniques of the fugue by infusing them with the vigour of his post-Wagnerian tonal-harmonic vocabulary.

Szymanowski and Strauss are treading two opposite paths here. Szymanowski is moving away from his classical models while trying to conceal his reliance on some of their factors of coherence that have proven to be reliable. Strauss, on the contrary, makes no secret of his borrowing of historical models, notably the model of the fugue, but wants to give them fresh life. These contrasting attitudes could be shown to carry equally contrasting epiphanies, but, as I hope to prove, they are not so dissimilar as they may seem at first glance.

On the one hand, Szymanowski is explicitly striving to break the shackles of Austro-German post-Romanticism, in which he felt he had been held captive earlier in his career. He willingly opens his work to the refreshing influence of French Impressionism and, to a certain extent, of Russian primitivism. Yet neither Impressionism nor Primitivism were of any help in achieving largescale coherence, while the Austro-German academic tradition offered him tools well honed for this purpose. In his subtle recourse to these tools, Szymanowski performs the musical equivalent of a hostile takeover: the formal processes typical of the academic tradition are assimilated in a work dominated by Impressionistic harmonies and pseudo-Oriental melodies and rhythms. It is debatable whether the Impressionistic elements have gained from the takeover or, on the contrary, that the Austro-German academic tradition has succeeded in carving a foothold in an area of music which was openly rejecting its influence.

Strauss certainly shows no intention of rejecting the influence of his Austro-German environment, but, in a way different from Szymanowski he is also performing a hostile takeover. This time, it is the history of music that falls victim to the composer's scheming. The prelude and fugue genre, specifically identified with music of the Baroque period, is called to serve under the modern flag of post-Romantic harmonies. This comes to the fore particularly in the fugue. Following the first performance of the motet, critics were quick to seize on that portion of the work, which they considered disproportionately long. They missed the point that Strauss was trying to make: that he could write fugues longer and more complex than those of the great Bach himself.

Thus, both Szymanowski's Third Symphony and Strauss's German Motet can be seen as epiphanies of the musical culture of the Western world coming to terms with foreign elements. In the case of Szymanowski, these "foreign" elements are the new melodic, harmonic and rhythmic resources tapped by Impressionism and Primitivism, and beyond these, the resources of musical cultures outside the European mainstream. In the case of Strauss, it is the historicization of the repertoire. By historicization, I mean the growing infatuation with works of the past that the musical world was beginning to experience 
at the turn of the twentieth century, as opposed to the preference it had shown, up to that time, for the works of contemporary composers.

\section{CONCLUSION}

This paper holds no pretense at giving an exhaustive account of the epiphanies at work in Szymanowski's Third Symphony. Among other things, little has been said of its motivic content or its tonal plan. Through an examination of Rumi's text, of the texture, and of the melodic, harmonic and formal components, and by having recourse to the foil provided by Richard Strauss's Motet, I hope to have shown some of the many epiphanies which one may witness in this symphony. Moreover, I hope to have shown how this concept of epiphany can help break the artifical barriers erected between the meticulous tabulation of the structures of music, to which analysts are committed in the name of scientific responsibility, and the passionate disquisition of its expressive content, deemed too subjective to carry any pretense of rational validity. All the components of the symphony that I have examined have an objective existence. Their interpretation as epiphanies may be the outcome of a personal, presumably subjective process, but it is based on solid facts open to dispassionate inquiry.

As I have already mentionned, Strauss was born, raised, and he died an agnostic. Szymanowski was raised a Catholic and, although he was not a devout follower of the Church, he has always remained atuned to the spiritual values of his faith. It is no little irony that Strauss was to write a work epiphanic of the moral universe of nineteenth century Christianity, with its belief in reward in afterlife for the fulfilling of one's mission in this valley of tears, while Szymanowski was exploring a non-Christian, hospitable universe infused with the loving presence of God.

\section{REFERENCE LIST}

Blezzard, Judith. 1991. "Richard Strauss A Cappella." Tempo no. 176, 21-28. Cadrin, Paul. 2002. "Between Dawn and Dusk: The Song of the Night and the Symphony at the Turn of the Century." In The Songs of Karol Szymanowski and his Contemporaries, ed. Zofia Helman, Teresa Chylińska, and Alistair Wightman, 112-121. Los Angeles: Polish Music Center.

Dibble, Jeremy. 2001. Notes to Szymanowski: Stabat Mater; Six Kurpian Songs; Symphony No. 3 "The Song of the Night." Russian State Symphony

Cappella; Russian State Symphony Orchestra under Valerie Polyansky.

Chandos 9937. Colchester, England : Chandos Records.

Lewis, Franklin D. 2000. Rumi-Past and Present, East and West: The Life, Teaching and Poetry of Jalâl al-Din Rumi. Oxford: Oneworld.

Lomax, Alan. 1968. Folk Song Style and Culture. Washington: American Association for the Advancement of Science.

Samson, Jim. 1980. The Music of Szymanowski. London: Kahn \& Averill.

Strauss, Richard. 1943. Deutsche Motette/German Motet, nach Worten von Friedrich Rückert (English Words by Alfred Kalisch), für 4 Solostimmen 
und 16 Stimmigen gemischten Chor a Cappella, op. 62. London: Boosey \& Hawkes.

Szymanowski, Karol. 1985. III Symfonia, „Pieśń o nocy” op. 27 na tenor solo, chór mieszany i wielką orkiestrę do słów Dżalaluddina Rumiego $w$ przekładzie Tadeusza Micińskiego, redakcja Teresa Chylińska. Kraków: Polskie Wydawnictwo Muzyczne.

Taylor, Charles. 1989. Sources of the Self: The Making of the Modern Identity. Cambridge, Mass.: Harvard University Press.

\begin{abstract}
According to the philosopher Charles Taylor, since the beginning of the nineteenth century, with the advent of Romanticism, the work of art is defined by its epiphanic character. It is a manifestation of something of the highest moral or spiritual significance; this manifestation is not merely subjective, in which case it would be inaccessible to scholarly inquiry, but it has an objective character. The Third Symphony, op. 27, by Karol Szymanowski is analyzed in the light of Taylor's concept. The Deutsche Motette, op. 62, by Richard Strauss, which is based on a text similar to the one used by Szymanowski, serves as a foil to buttress the findings.
\end{abstract}

\title{
Résumé
}

D'après le philosophe Charles Taylor, depuis l'avènement du Romantisme, au début du dix-neuvième siècle, l'œuvre d'art se définit par son caractère épiphanique. Elle est le lieu de la manifestation d'une réalité de la plus haute importance morale et spirituelle; cette manifestation n'est pas purement subjective, ce qui la rendrait imperméable à l'examen scientifique, mais elle a un caractère objectif. La Troisième symphonie, op. 27, par Karol Szymanowski est analysée à la lumière de la théorie de Taylor. La Deutsche Motette, op. 62, de Richard Strauss, basée sur un texte similaire à celui utilisé par Szymanowski, sert de repoussoir pour confirmer les conclusions. 